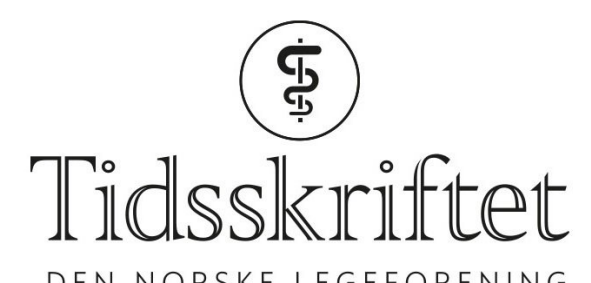

DEN NORSKE LEGEFORENING

\title{
Detaljkunnskap eller overblikk?
}

TIDLIGERE I TIDSSKRIFTET

SYNNE LOFSTAD

E-post: synne.lofstad@hotmail.com

Redaksjonssjef i Æsculap

Hvor stor plass allmennpraksis får i studiet er stadig debattert i Æsculap. I 1979 deler fire nyutdannede leger sine tanker rundt studiet og hvorfor man sliter med rekruttering til allmennpraksis. Som nyutdannet i 2020 kan undertegnede skrive under på mye av dette samme, særlig det om hvor drillet man som student er i avansert behandling av ulcerøs colitt og morbus Crohn, uten å ha den minste formening om hvordan man møter en pasient som søker hjelp for diaré for første gang (Æsculap 1979; 59: 9, 11).

\section{Studiet og unge legers instilling til almenpraksis}

(...) Rekrutteringa til primærhelsetjenesta er for dårlig. Analysene rundt årsaksforholdene bak dette, er mangfoldige. Svære økonomiske løft rundt etablering av privatpraksis og almenpraktikerens arbeidssituasjon er sjølsagt tungtveienede grunner for at nyutdannede leger kvier seg for å søke almenpraksis framfor sykehusmedisin. Men noe som ofte savnes i debatten er spørsmål om de nye legenes faglige motivering for å søke almenpraksis er god nok. Spørsmål til medisinerkull tidlig i studiet viser ofte at en stor prosent har planer om å gå inn i almenpraksis. Skjer det så noe i løpet av studiet som påvirker motivasjonen for almenpraksis i negativ retning? 


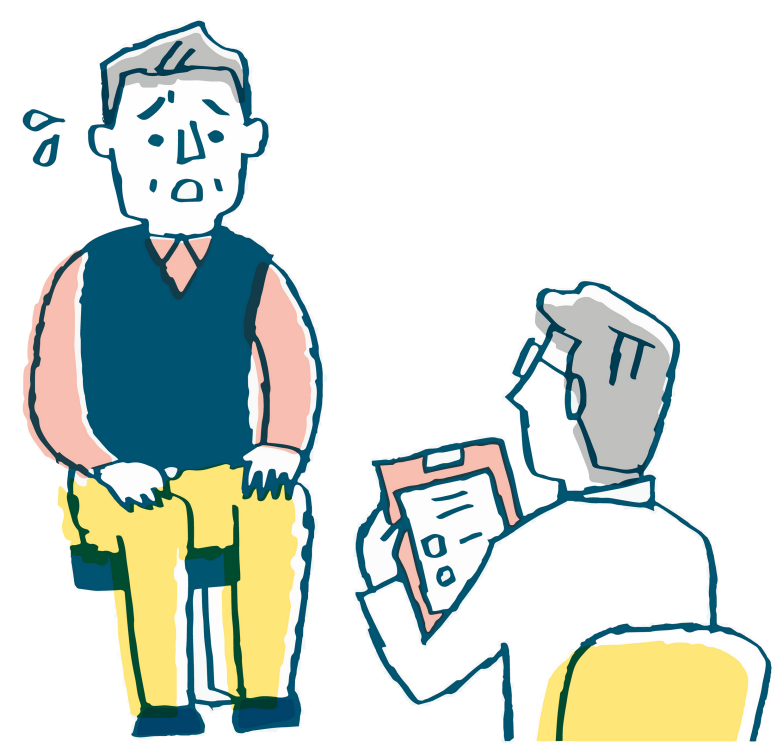

Illustrasjon: Hisa Nishiya / iStock

Ja, mener undertegnede, 4 helt ferske leger. Vi har alle studert i Oslo, og med bakgrunn i undervisningsopplegget har vi gjort oss opp noen tanker. Vi har praktisk talt utelukkende blitt undervist av spesialister som sjølsagt på godt og vondt ser alt ut fra sin innfallsvinkel.

Rekrutteringa til primærhelsetjenesta er for dårlig

Det en kanskje kan spørre om, er om det er noen rimelig sammenheng mellom den vekt det blir lagt på detaljer og den nytten vi vil få av disse seinere, evt. når den tid kommer, hvor mye vil sitte igjen da.

Rikshospitalet er et sykehus preget av sjeldenhetene. Svært få av de pasientene som søker primærlege blir henvist til spesialsykehus. I tilsammen fem terminer ble vi i klinikken drillet i ulcerøs colitt og morbus Crohn, slik at de fleste av oss på stående fot vil kunne servere behandlingsprinsipper for ulike former for fulminante colitter, mens svært mange vil klø seg i hodet når de for første gang står overfor en akutt diaré som må stoppes. Som et eksempel på at en rekke vanlige lidelser ikke når oss i studiet kan nevnes at på nest siste uketjenestedag i studiet, kom det fram at halvparten av en gruppe på 10 studenter aldri hadde palpert et brokk. Det samme gjalt folkesykdommen varicer. Da en velvillig lektor innkalte pasienter til neste dag, hadde ryktet bredd seg på kullet om at en nå kunne få se brokk og varicer, og dette førte til at flere studenter fra andre uketjenestgrupper møtte opp. Vi har praktisk talt utelukkende blitt undervist av spesialister som sjølsagt på godt og vondt ser alt ut fra sin innfallsvinkel

Eksamensforma slik den er i dag premierer for en sto del spesialistkunnskaper. Sjøsalgt er det gunstig å ha fătt skikkelig innsikt i en spesialitet, men det spørs bare hvor mye av detaljene vi vil få nytte av seinere. I kjemi/biokjemi som har fătt mye tid i undervisninga, lærte vi en hel del puggstoff. Dette er stoff som sikkert vil komme oss til gode dersom vi går inn i forskning, og en del har vi nok kanskje brukt som grunnlag for forståelse av enkelte ting i klinikken. Men den store vekta som er blitt lagt på disse fagene, synes noe underlig når vi sammenholder dette med det forsvinnende lite vi vet om f.eks. psykiatria minor og skjelett/muskellidelser, lidelser som kommer til å oppta en stor del av vår tid i almenpraksis.

Vi har i løpet av studiet dessverre en rekke ganger konstantert hvordan en del av våre undervisere harselerer over uvitenheten til innleggende kollegaer når det viser seg at innleggelsesdiagnosen har vært uriktig. Det som lett glemmes er at sykehusspesialisten for det første arbeider med et langt mindre felt, og for det andre har et helt annet apparat i 
ryggen når det gjelder undersøkelsesmuligheter. Slikt bidrar i alle fall ikke i positiv retning når det gjelder å heve anseelsen av almenpraktikeren. Dessuten bidrar det til følelsen av at der er «fa'lig» å være enslig doktor, for sjelden har vi inntrykk av at sykehuskollegaen gir feed-back til den uvitende i praksis slik at man kan lære av sine feil. Møter vi nedsettende bemerkninger fra våre autoriteter mange nok ganger, vet vi at det setter spor, og dersom en ba studentene på et avgangskull om å rangere forskjellige spesialiteter, inklusive almenpraksis, er vi ikke tvil om utfallet!

Dessuten bidrar det til følelsen av at der er 'fa'lig' å være enslig doktor

Resultatet av alt dette kan så lett bli at vi etter studiets avslutning føler almenpraksis som noe ukjent. Vi føler angst for almenpraktikerens ansvar. Vi er lært opp i et sykehussystem, vi kjenner dets rutiner, og de hjelpemidlene vi her har i ryggen. Våre forbilder har vært sykehusleger, og kanskje er vår mening også at det er spesialistene som har drevet det til noe i sin karriere.

Hva bør så gjøres for å endre på dette? Etter vår mening bør studiet rettes mer mot almenpraksis. Sykdomspanorama i almenpraksis må i større grad bli del av pensum. Skikkelig obligatorisk uketjeneste i faget almenpraksis bør innføres. Derigjennom lærer vi almenpraktikerens arbeidsområde tidligere å kjenne, almenpraktikeren blir en del av våre modeller, og vi får kanskje lære å utføre en del enkle praktiske ting også (noe studiet ellers mangler). Sykehuslegene bør dessuten få en mer bevisst holdning i omtalen av almenpraktiserende kollegaer.

Publisert: 5. juni 2020. Tidsskr Nor Legeforen. DOI: 10.4045/tidsskr.20.0407

(C) Tidsskrift for Den norske legeforening 2020. Lastet ned fra tidsskriftet.no 